\title{
24 \\ Is There Such a Thing as an Antiwar Film?
}

\author{
Agnieszka Soltysik Monnet
}

The question posed by the title of this essay can be framed in relation to the following paradox: On the one hand, most serious filmmakers since the Vietnam War who make war movies claim to be condemning war or at least criticizing some particular war; ${ }^{1}$ on the other hand, there is the claim widely attributed to François Truffaut that it is impossible to make an antiwar narrative film, because any film will inevitably sanitize and glamorize war (Ebert, 1996). Ultimately, I believe that Truffaut is more right than wrong, though in this chapter I will examine the many ways that some very fine and ambitious films from various countries have attempted to discredit and demystify war. The terms that I have opted to use to describe the opposing strategies of representation around the issue of war are "enchantment" and "disenchantment." Like Sarah Cole, who has argued that these are two "principles around which literary engagements with violence have tended to cluster," I have found this dichotomy helpful in understanding how filmmakers attempt either to endow warfare with positive meanings and affects or to strip it of both (Cole, 2009, p. 1632). I will start by examining some of the theoretical questions and complications raised by the very notion of "antiwar film."

The first question that my title begs is "what is an antiwar film?" A common-sense understanding of the antiwar film that is found on a number of internet sites sees it as focused on the "pain, horror and human costs of armed conflict" (Wikipedia, 2013). Yet here we run into a first complication. Many films that present war as painful, horrific and costly also represent it as important and necessary. Certainly few films depict the pain and horror of war more graphically and powerfully than Steven Spielberg's Saving Private Ryan (1998), but it would not make sense to call this reverential military melodrama an antiwar film. After the first 30 minutes of combat, the conventions of Hollywood narrative re-emerge to frame the violence in a series of reassuring clichés demonstrating that, while the Normandy invasion was indeed costly and gruesome, its protagonist conducts himself stoically and bravely, the army keeps track of every single death and watches maternally over the fairness 
of who is exposed to danger, and the object of the successful rescue mission-Ryan (played by Matt Damon)-lives to be a beloved grandfather remembering and honoring those who fell. No other film has done so much to restore luster and honor to the American military war and to war as a noble activity in the post-Vietnam era than Saving Private Ryan, so focusing strictly on the "pain, horror and human costs" of the ultra-violent opening section is misleading with regard to its ultimate stance on war.

The Wikipedia "list of antiwar films" also points out that antiwar films can be critical of war in general or a specific conflict in particular. Herein lies another qualification to the question of what an antiwar film is exactly. Thus, films that denounce a specific war may not necessarily depict all war as necessarily wrong. Conversely, films that depict war in general as costly and horrific may nevertheless suggest that a specific war is necessary and worth the cost. In fact, this brings us back to Saving Private Ryan, which depicts combat as brutal but World War II itself as sacred and its generation's sacrifice as deeply honorable. In fact, one would be hard-pressed to find any film that suggests World War II was not an important war to have fought and won. ${ }^{2}$

What then do we mean exactly by an antiwar film, and how would it work? It appears far easier to grasp the meaning and gauge the effects of pro-war films. These are films that represent wars as effective rites of passage and as valid means of becoming a man. Some will represent war as important and valued by society, usually some particular war but often, by extension, these films suggest that war is a legitimate and necessary practice in general. Pro-war films sometimes have the effect of sanitizing war, making it look cleaner and less destructive than it really is, but more often they will present it as brutal but morally necessary, militarily effective, and irresistibly exciting. Many will present death and sacrifice as ways to gain recognition, respect, remembrance, and admiration from other men and from society in general. To evoke Wilfred Owen's famous revision of Horace, pro-war films tell the "old lie" that dying for one's country is both "dulce et decorum," which can be translated roughly as "sweet and just." Pro-war films strive to enchant war, in the sense that Sarah Cole has defined it, by endowing violent death with generative value, representing it as something "positive and communal, perhaps even sacred" (Cole, 2009, p. 1634). During World War II, according to Clayton R. Koppes and Gregory D. Black (2007, p. 66), the Office of War Information asked filmmakers to consider the question "Will this picture help win the war?" Film historians have amply documented how enthusiastically Hollywood answered the call to present war films that would "help win the war" (Schatz, 2006; May, 2006). Even before the war, Hollywood had warmed up to the prospect of convincing a nation of isolationists that war was a duty they should embrace with the Gary Cooper film Sgt. York (1941), a biographical film about a deeply religious farmer who became a decorated hero in World War I despite his misgivings about how to reconcile his moral obligations to God with those to his country. Sgt. York was so clearly a pro-war film that it became embroiled in legal controversy about violating America's official neutrality laws until the attack on Pearl Harbor rendered the controversy moot (Koppes and Black, 1987, pp. 39-47).

Though perhaps crude, one of the clearest ways to determine if a pro-war film has succeeded in convincing viewers that war is valuable, either personally or politically, is to look at enlistment rates. In the history of cinema, there have been a number of films that are linked to a rise in military enlistment or that are regularly shown to new recruits as a way to inspire and reassure them. Among the most important is Alan Dwayne's The Sands of Iwo 
Jima (1949), the film that catapulted John Wayne to military glory and cult stardom. It is a film that loomed large in the military imagination of the Vietnam generation, directly or indirectly inspiring untold numbers to enlist. For example, William Broyles Jr., veteran and writer, recalls that "we ... were primed [for Vietnam] with Sands of Iwo Jima" (quoted in Wechsler, 2005, p. 74). In his decidedly antiwar memoir Born on the Fourth of July (1976), Ron Kovic also describes his childhood adoration of the film: "Every time I heard it [the Marine Corps Hymn] I would think of John Wayne and the brave men who raised the flag on Iwo Jima that day. I would think of them and cry" (Kovic, 1976, p. 55). Lawrence H. Suid reports that when a group of recruits at Camp Pendleton in the early 1960s was asked why they had joined the Marine Corps, half of them answered that they had enlisted "because of the John Wayne movies they had seen" (Suid, 2002, p. 131). The curious thing about Sands of Iwo Jima as a pro-war film is that it does not portray war as easy and heroic; there are moments of terrible moral doubt as well as painful losses of comrades, but the film ultimately suggests that the war is important and that death will be rewarded with honor. The nondiegetic singing of the Marine Corps Hymn moments after Wayne's character is shot by a sniper after the battle reinforces the message that his death is not in vain even if it seems tragically unnecessary.

Many other films have been associated with enlistment boosts or recruitment. Thomas Doherty reports that "several Selective Service boards" claimed that the film Sgt. York convinced "pacifist ministers and conscientious objectors" to lose their qualms about "combat duty" after viewing the film (Doherty, 1993, p. 102). John Wayne's pro-Vietnam War vehicle, The Green Berets, may have been panned by critics but it was successful at the box office and has been linked to a spike in recruitment rates in 1968 (Suid, 2002, p. 256). Similarly, Top Gun (1985) boosted the image of American fighter pilots in the 1980s and helped return luster to the tarnished reputation of the American military after the Vietnam War. Finally, Lee R. Ermey, actor and former drill instructor, claims that Kubrick's Full Metal Jacket (1987) was one of the "most influential pictures of all time as far as recruitment goes," thanks especially to his performance as the tough drill instructor. Ermey writes that "even today, seventeen years later, there's not a day goes by on the base but what at least one person doesn't come up and tell me I'm the reason they're in the Marine Corps. Full Metal Jacket was their motivation. I think that movie, The D.I., and Sands of Iwo Jima were probably the most influential pictures of all time as far as recruitment goes" (Smith, 2006, p. 160).

But how to gauge antiwar effects? American autobiographers do not often write of films that turned their hearts against war, though some films probably can and have done so. Although this essay is about the narrative film, it should be said that documentary films may be able to have clearer positions against war and may therefore have more powerful and long-lasting effects on viewers' attitudes and beliefs. Films such as In the Year of the Pig (1968), Winter Soldier (1971), and Hearts and Minds (1974) combine testimony with historical record and skillful editing to create powerful critiques of the Vietnam War in particular and of war and its effects on soldiers and civilians in general. The reality effect of documentary, though constructed and open to manipulation, lends documentary film traction and weight that fictional narratives do not have.

So, why make a fictional film against war? Why choose narrative over the documentary format and what can such a film hope to do? Practically speaking, one obvious answer is distribution. A narrative film can hope to have a greater circulation than a documentary,

wh

Aes

eng

Tor

the

pol

Lite

tha

auc

(H

em

of $I$

pro

as

his

em

cha

eng

ope

are

pro

the

mo

"ap]

of $t$

by

a st

In

197

can

the

per

aest

in $g$

app

tior

of $h$

em

sho

heig

and

film 
which tends to be watched mainly by those who already agree with its argument. Aesthetically, the main advantage of narrative over documentary is the heightened ability to engage viewers' emotions. As Harriet Beecher Stowe said of her own political novel, Uncle Tom's Cabin (1852), making people "feel right," that is, feel "strongly, healthily and justly, on the great interests of humanity," is already of great benefit and involves doing something political (Stowe, 1984, p. 385, emphasis in original). Similarly, in a recent issue of War, Literature and the Arts, Thomas Horne writes that "great political film making can do more than help its audience to understand the political landscape differently, it can get under its audience's skin and force it to feel its own mistakes and change its self understanding" (Horne, 2010, emphasis in original). Although documentary films can also engage viewers' emotions, narrative film often does it better and more powerfully. Horne uses the example of In the Valley of Elah and the specific strategy of inviting the audience to identify with the protagonist, a father played by Tommy Lee Jones, looking for his missing son, only to realize as the film progresses that this character may have himself been responsible for the loss of his son, indirectly, through his blind adherence to military values. Horne argues that this empathy and then gradual recognition of the limitations of the character as well as the character's own coming to consciousness serve as a model for how a political film can engage viewers both intellectually and emotionally.

However, Horne's view that a good political film will "force" a viewer to feel something opens up a number of theoretical questions. First of all, the actual mechanics of how films are perceived, interpreted, and understood are far more complex than most debates about pro- and antiwar films seem to acknowledge. The field of spectatorship studies emerged in the 1970s-based on semiotics, Marxism, and Lacanian psychoanalysis-and proposed a model of film reception that gave the camera enormous power of persuasion. The so-called "apparatus theory" of spectatorship assumed that the camera's point of view and organization of the visual field did effectively "force" the viewer to accept the "subject-position" implied by the camera's perspective, especially in realist cinema, where the illusion of objectivity and transparency was most insistently cultivated. The viewer was said to be "sutured" into a specific visual and, by consequence, ideological position, and Horne's argument about In the Valley of Elah seems to assume the film will work in this way (Silverman, 1986).

However, this model of spectatorship has been soundly revised and qualified since the 1970 s, and spectatorship studies currently acknowledge vast differences in the way viewers can understand a film. For example, spectators have different interpretive lenses (such as, their political stance or expectations about the genre of the film) and baggage (namely, personal and cultural background) informing their interpretive framework. The reception aesthetics pioneered by Wolfgang Iser (stressing readers' active interpretations of narrative in general) along with feminist critiques of the inflexible and gender-blind nature of the apparatus theory model (e.g., Judith Mayne, Janet Staiger), and empirical studies in reception and spectatorship, have all contributed to refining and expanding our understanding of how films create meaning (cf. Iser, 1978; Staiger, 1992; Mayne, 1993). One thing that has emerged from this research is the notion that narrative film, like all narrative that works by showing rather than telling, creates openings for different readings. Thus, the cost for the heightened emotional involvement that narrative cinema can offer is an inevitable ambiguity and instability of meaning. Even films that Martin Barker, in his discussion of Iraq war films, calls "statement films," will be subject to multiple readings and positionings by 
directors, producers, and actors, and none of these can claim to be a definitive statement of what a film "intends" to say nor how it will be understood (Barker, 2011, pp. 119-120). As veteran and writer William Broyles Jr. says of the war film in particular: "Older men write about the truth of war as a cautionary tale, but young men hear the stories, they read the books and see the films, and they just can't grasp the warning, it's simply not the part that gets through" (quoted in Wechsler, 2005, p. 74).

Claudia Springer has written about the combat sequence as a particularly ambiguous moment in the war film, in which visual excess overwhelms narrative logic and invites the spectator to lose him/herself in "the pleasure of looking" (Springer, 1988, pp. 480). These are moments of "highly charged emotions" and are therefore "not well suited to conveying an antiwar message" (ibid., p. 483). Instead, combat sequences inspire "many conflicting, even contradictory, tendencies" and "open themselves up to multiple readings" (ibid., p. 484). Springer argues that "the onus for conveying an antiwar message ultimately falls on the narrative, for it has to compensate for the more ambiguous signifying system of spectacle" (ibid.). However, as we saw above, narrative does not necessarily provide the simple and unambiguous message that could counteract the seductions of spectacle and effectively cancel out its pleasures.

Further complicating the ability of narrative fiction films to effectively convey any clear political "message" is the larger economic and institutional pressures on filmmakers, even independent ones. A film must please an audience and not simply preach. In order to do so, it must entertain at least to some extent, and this necessarily dilutes the clarity and intensity of any so-called message. Moreover, most filmmakers see themselves as telling a story or exploring an issue, while also creating a work of art, and therefore not interested in simply conveying a message. Thus, most films, even if tending toward an antiwar position, will qualify and complicate their plots with other purposes and values. Hollywood films, produced to succeed commercially, will often "balance" antiwar themes with patriotic or pro-military gestures or celebrations of individual heroism or sacrifice. As Michael Wayne said of The Green Berets, which his father intended as a pro-war propaganda vehicle, ultimately what counts is that "we're in the business of selling tickets" (quoted in Lichty and Carroll, 2008, p. 392). In fact, most films are quite simply ambivalent in their representation of war. They will criticize military authority but glamorize the toughness of grunts, or denounce the effects of war on soldiers while portraying their sacrifice as noble and necessary. Even independent filmmakers will generally prefer an aesthetics of irony and ambiguity to an uncompromising denunciation of war.

In order to take an absolutely unqualified antiwar position, a film would need to show. war not only as ineffective, morally wrong, destructive to the soldier, civilian, and society that accepts it, but also to show death in combat as meaningless and utterly unredeemed. The greatest taboo of militarism is the possibility that military deaths are in fact "for nothing," as a Japanese soldier in Clint Eastwood's Letters from Iwo Jima (2006) worries. The ideological underpinning of the military as an institution depends on the fiction that every soldier's death matters, that it has agency, that it strengthens the nation for which it allegedly occurs, either militarily or in some other more mystical way, often figured through the ritual power of sacrifice.

If the task of the antiwar film would be to disenchant war, to strip it of all magic and illusion, and deny combat death its ritual and cultural power, the problem is that many 
aspects of narrative film connive against disenchantment. The film medium is far more effective at re-enchantment, at activating myth and creating magic through spectacle. This is truer than ever at the present moment, in an age of the digital and infinitely malleable image. Take, for example, the traditional task of the antiwar poem or work of art. The goal, as Wilfred Owen so eloquently said, was to refute the "old lie" by showing the truth. Thus, realism has been central to antiwar aesthetics ever since Walt Whitman regretted that "the real war will never get in the books" (Whitman, 1996, p. 802). Antiwar art has thus largely conceived of itself as attempting to show some aspect of "the real war." Specifically, this has usually been understood as the horror of carnage, the ubiquity and finality of death, mutilation of the mind and body, the role of chance and accident, the fallibility of officers, and the cruel and brutal actions soldiers are often obliged to do. In keeping with this aesthetic imperative, Civil War veteran and writer Ambrose Bierce's most antiwar story, "Chickamauga," is the most graphic and gruesome of all his Civil War fiction, describing soldiers as dehumanized and broken things crawling on the ground or pulling themselves along with useless legs dragging behind (Bierce, 1966, p. 50). Similarly, Wilfred Owen counters the "old lie" in "Dulce and Decorum Est" with the truth of chemical warfare and the gruesome asphyxiation of a victim of mustard gas (Owen, 1963, p. 55).

Yet the evolution of the post 1970 s war film has changed the rules of the game by pushing the realism of mutilation and injury to hyperrealistic extremes. The number of missing limbs, decapitations, spilled intestines, and blood sprays per frame in Spielberg's Saving Private Ryan probably surpassed the reality of the Normandy landing and condensed hours of carnage into 30 dramatic minutes. Yet, as said earlier, the film cannot be credibly called an antiwar film because of the redeeming narrative that frames this violence and lends it generative power, in short, re-enchants it. Moreover, due to the dynamics of genre spectatorship, most viewers of war films now expect to see graphic injury and assume each new war film will surpass previous ones in gruesomeness. ${ }^{3}$ Graphic representation of injury is in fact the main criterion for what passes as "realism" in the war film in general, which is all the more paradoxical if one thinks of the ubiquity of ultra-realistic mutilation that has become commonplace in the horror film genre (e.g., the Saw series). Thus, the war-film-aspornography comparison is not entirely misguided when we think of how viewers expect to be excited and moved by it.

The imperative for the war film to convince viewers of its realism has led to the now common convention of spraying the camera lens with blood (e.g., We Were Soldiers, Saving Private Ryan). The purpose of this device seems to be to suggest that the film is like a documentary or that the camera is really there in the middle of the battle, and so the spectator is there by proxy or by extension as well, even though, ironically, the blood on the lens convention simultaneously displays the artifice of the scene by reminding readers that it is being filmed by a camera. Moreover, it equally ironically seems to serve as a shield for the viewer, a safe barrier. Blood on the lens means no blood on the viewer's face, as if that were possible, if only for the moment that the viewer is absorbed in the illusion of the film's world. Another way of saying this is that combat on film, no matter how hard it tries to create a reality-effect, can never be anything but safe, vicarious play. And therefore it will never create the terror and danger of what it means to be in combat. World War II veteran and film-maker Samuel Fuller once said that for a film to be "truly true to the actual nature of war, bullets would need to be spraying out from the screen, taking out members of the 
audience at random, one by one, in scattershot carnage" (quoted in Wechsler, 2005, p. 77). Instead, heightened realism only reinforces the illusion of immortality that Herr describes "wiping out" an entire generation of boys in Vietnam (Herr, 1978, p. 225). "I keep thinking of all the kids who get wiped out by seventeen years of war movies before coming to Vietnam to get wiped out for good," Michael Herr writes (ibid.). In short, films that depict combat directly on screen will be the least likely to disenchant it. As Francis Ford Coppola puts it, "Violence breeds violence. If you put a lot of it on screen, it makes people lust for violence" (quoted in Suid, 2002, p. 343). One of the most cited proofs of this is Anthony Swofford's claim at the beginning of Jarhead that all "filmic images of death and carnage are pornography for the military man; with film you are stroking his cock, tickling his balls with the pink feather of history, getting him ready for his real First Fuck." No matter what the filmmaker intended, and regardless of how many civilians will "watch the films and weep and decide once and for all that war is inhumane and terrible," the fact remains that "all Vietnam war films are pro-war films" (Swofford, 2003, pp. 6-7).

Furthermore, ironically, by creating suspense, tension, and an approximation of adrenalinfueled excitement, the Hollywood war film seems to be able to tap into an aspect of combat that antiwar films tend to underestimate, namely its pleasures. The seductiveness of war is Michael Herr's guilty theme in Dispatches and again more fully developed in the documentary film First Kill (2001), which features Herr as narrator and veterans of the Vietnam War discussing the way killing made them feel intensely alive. Vietnam veteran and Hollywood screenwriter William Broyles Jr's notorious 1984 article for Esquire, "Why Men Love War," covers the same theme, with even more gusto. Broyles argues that "the love of war stems from its being an experience of great intensity; its lure is the fundamental human passion to witness, to see things, what the Bible calls the lust of the eye and the Marines in Vietnam called 'eye fucking.' War stops time, intensifies experience to the point of a terrible ecstasy" (Broyles, 1984). Broyles pulls out all stops in his passionate defense of the taboo experience of loving war. He gives it cosmic dimensions, the "only way in which most men touch the mythic domains in our soul. It is, for men, at some terrible level, the closest thing to what childbirth is for women: the initiation into the power of life and death. It is like lifting off the corner of the universe and looking at what's underneath." Gendering war as inherently masculine, Broyles also reveals that the pleasure is essentially competitive and boyish: "War is a brutal, deadly game, but a game, the best there is. And men love games." It is also reassuringly simple, for Broyles: "War replaces the difficult gray areas daily life with an eerie, serene clarity. In war you usually know who is your enemy and who is your friend, and are given means of dealing with both" (ibid.).

Former war correspondent Chris Hedges has written a book describing the same phenomenon but without Broyles's celebratory enthusiasm. Hedges describes the intensity and moral simplicity of war as a kind of drug: the "rush of battle as a potent and often lethal addiction," and the "purpose, meaning and reason for living" as an "exciting elixir" (Hedges, 2002 , p. 3). The purpose of his book is not to justify war through its pleasures but to recognize them for what they are in order to learn better to avoid war. The Manicheanism and pleasurable emotional tension that Herr, Broyles, and Hedges describe is something that the combat film taps into, I believe. War films offer a certain kind of excitement through war scenes, as well as vicarious bonding and intimacy between men in arms, but most importantly they offer a safe and contained experience of "touching death," of losing a 
buddy, perhaps even weeping for him. War films are powerful melodramas for men (cf. Soltysik, 2008; Hanich, 2008). The characters that viewers identify with are often virtuous victims, scared, usually young, beleaguered, endangered, defined by suffering (Williams, 1998). For example, former high school English teacher Captain Miller (Tom Hanks) in Saving Private Ryan is bravely stoic on the surface but his trembling hand serves as a visible sign, so important to the genre of melodrama to identify the virtuous victim, that he is often frightened under the cool exterior. Yet all these elements will tend to re-enchant war and make it appear as the ultimate arena where a man tests his mettle, where one lives epic dramas of life and death, and where men can care for one another freely with no fear of being considered unmanly.

Nevertheless, although the film medium conspires to re-enchant war and combat, narrative fiction film has, since its inception, on many occasions strived to disenchant, demystify, and deglamorize war. The results are often mixed, but the attempts are interesting to examine. Certain strategies and conventions recur in films that wish to condemn war in general or specific wars. These include the following:

- the use of children as victims

- an emphasis on the youth of soldiers (related to the first strategy)

- a focus on the soldier's domestic roles and relationships (as child or parent or spouse)

- the depiction of both sides of the war, or humanizing enemy combatants

- a stress on death and dismemberment

- the depiction of the rape and abuse of women as allegories or inevitable results of war

- a focus on the psychological damage combat does to soldiers (shellshock, madness, PTSD)

- a conversion narrative (gung-ho soldier converts to pacifism through experience)

- cynicism towards military and/or political authorities

- satire (often linked to the previous trope)

- disruption of linear narrative and the meaning and sense of closure it confers

- a bleak or unexpectedly tragic ending (sometimes linked to the previous device)

- claims to historical authenticity (linked to the imperative to "tell the truth of war" discussed earlier)

- depiction of death as unredeemed and meaningless - a senseless waste

- and finally, an emphasis on the maddening sounds of war (pounding of artillery, bombs dropping, etc.) in order to offer an alternative to the spectacle of combat.

Since this list is too long to discuss in detail, I will examine several of these devices in relation to specific films.

Probably the most common and most powerful weapon in the antiwar film arsenal, if I may be permitted, is the child. Caroline Levander has extensively written about the cultural work of the child as trope for both "innocence and nation," a conjunction of associations that makes the child a particularly useful device for antiwar narrative (Levander and Singley, 2003 , p. 5). The child is essentially innocent, pre-ideological, nonpolitical, and yet easily made to symbolize national identity and its possible futures (ibid., p. 4). Moreover, children are small and weak and therefore make excellent protagonists of melodrama, which requires virtuous victims (Williams, 1998). Injury to a child is always necessarily perceived as an injustice and moral outrage, whereas injury to adults, even innocent civilians, sadly fails to 
carry the same ethical weight. It is no accident that the protagonist of Ambrose Bierce's short story "Chickamauga" (1891, see Bierce 1966) is little more than a toddler, one who begins the story by pretending to be a soldier only to end it in howls of grief when he discovers what real soldiers have done to his mother. Films that have focused on children in an effort to criticize the effects of war include Come and See (Soviet Union, 1985), where the main protagonist is a 14-year-old child-soldier; Grave of the Fireflies (Japan, 1988), an anime about World War II; Turtles Can Fly (Iran, France, 2004), a gritty and haunting film about children living in a Kurdish refugee camp on the Iraqi border on the eve of the American invasion in 2003; and The Children of Huang Shi (Australia, China, Germany, 2008), about a journalist who travels on foot for hundreds of miles with 60 Chinese orphans to escape from the encroaching Japanese Army.

Many films that do not focus primarily on children will use them at key moments to heighten emotional and moral effects. In The Hurt Locker (2008), for example, the only time the largely numb main protagonist seems visibly upset is when he believes insurgents have killed a boy he has befriended. However, The Hurt Locker is also exemplary of how films that are not antiwar at all will use children for dramatic and political effects. In fact, using children as victims of war is also a favorite rhetorical device of the pro-war film, only the message they help convey is that the enemy is so perverse and cruel that they will harm even defenseless children, whereas "our" side protects them and tries to keep them safe. The rhetorical effect of children in a war film is like writing with DayGlo" paint: It magnifies the film's emotional impact both crudely and irresistibly. John Wayne used two child actors extensively in his pro-Vietnam War vehicle The Green Berets (1968), making the rape and killing of a young Vietnamese girl a central event in the film and catalyst for the conversion of a skeptical journalist into a recruit (not one for subtlety, Wayne has the journalist literally enlist at the end of the film). A more recent example is Clint Eastwood's American Sniper (2014), based on the autobiography of Chris Kyle, famous for being the "most lethal sniper in U.S. history" (Kyle, 2012). Kyle opens his book with an anecdote of killing an Iraqi woman who is about to throw a grenade at American soldiers. Eastwood rewrites the scenario to make Kyle have to kill first a child, who runs toward the convoy with an RKG Russian grenade, and then the woman who picks it up from the dead boy. Far from wondering what would motivate such fierce resistance to the US military presence, or whether any such incidents actually occurred, the film presents the insurgents in an apolitical way as deceitful "savages" whose only objective seems to be to harm Americans. In this case, then, instead of criticizing the war, the use of children serves only to underscore the savagery of the enemy and therefore the righteousness of Kyle's killing-a rhetorical strategy that dates back to the Indian Wars in the United States and Britain's colonial wars, when the savagery of the natives was regarded as justification for large-scale exterminations (cf. Dawson, 1994, pp. 87-92).

A related antiwar tactic is emphasizing the extreme youth of soldiers. ${ }^{4}$ One of the best instances of a film that uses child soldiers as the crux of its antiwar argument is the German film, Die Brücke (The Bridge), a 1959 West German film made by Austrian filmmaker Bernhard Wicki. Based on an actual event, the film is about a group of sixteen-year-old boys who are drafted in the last months of the war in 1945. Excited by the war and unaware of its dangers, they are left after only one day in the army to guard the village bridge, a task intended to keep them out of harm's way. However, due to a series of accidents and unforeseen 
circumstances, they find themselves defending the bridge against American tanks and end up dying one by one. A particularly wrenching scene has one of the boys shoot an American who has just told him to cease fire and go home or to the "kindergarten," angering the boy who has understood the word. He shoots the man in the stomach and the audience must watch the American writhing on the ground in pain while another boy begs the first to finish him off, only to discover that the first boy has already died from machine gun fire. Incidents like these, many of which are caused by accidents or foolhardiness, accumulate until only two boys are left. When three German soldiers show up to blow up the bridge, the boys realize their friends have died in vain and kill one of the soldiers in a fit of mad rage. One more boy dies from a gunshot at the hands of the German soldiers and finally the last boy staggers off the bridge, probably driven mad.

Besides the extreme youth of the soldiers-emphasized at the beginning of the film by glimpses of their adolescent romances and domestic dramas with parents, and reinforced by frequent close-ups of their extremely youthful faces-the other antiwar strategy used in this film is that of emphasizing the futility of their deaths. As mentioned before, the fear that death is in vain is the ultimate taboo that haunts military endeavors and their representations in culture. What drives the two last survivors to their desperate final act of killing another German soldier is the realization that their friends have killed and died for nothing, which the film represents as driving them literally insane. To hammer home the point, the film ends with a frame inserted just before the credits that reads: "This event occurred on April 27, 1945. It was so unimportant that it was never mentioned in any war communiqué." This epigraph, or epitaph, belies the myth that every combat death will be rewarded with fame and honor for the man who gives his life for his country. The lives of these boys on the threshold of adulthood have been snuffed out and forgotten by military history. The large role played by accidents and miscommunications in the plot of the film also suggests that these types of problems are common in war situations, and not only for the losing party. By undermining the myth that war is conducted rationally and efficiently, the film attempts to drive home a larger critique of war as a political strategy and human experience in general.

An American film that makes similar moves is George Roy Hill's 1972 adaptation of Kurt Vonnegut's Slaughterhouse Five (the novel was published in 1968, the film released in 1972). Both the novel and film emphasize the extreme youth of the protagonist, Billy Pilgrim, his virginity, passivity, and general helplessness, which the book (subtitled "The Children's Crusade") explains as typical of soldiers in combat. The narrator claims that soldiers are often not only very young, but also so lacking in agency because of how war is conducted that they can hardly be considered "characters" (in the sense of characters in a book). Both book and film demonstrate this with the science fiction analogy of showing Billy travelling helplessly through time throughout his life, almost never making a choice or decision. Death in the book and film is always pointless and in vain, an accident, and in the case of Billy's friend Derby, a schoolteacher shot for looting a tea kettle in the aftermath of the firebombing of Dresden, grotesquely ironic. There is an entire cluster of films that are otherwise very different from each other but which all emphasize the extreme youth of the soldier-protagonist and the pointlessness of his death, and use his death as the sudden and final scene of the film, thus ending the narrative with a graphic portrayal of war's cruel arbitrariness: All Quiet on the Western Front (1930), Gallipoli (1981), and Overlord (1975). 
By far the most common narrative convention of the war film in general is to focalize on a single soldier, usually an infantryman or "grunt." This strategy, however, has been criticized by many critics (such as Aufterheide, Sturken, and Kinney) for its narrowness and tendency to align the viewer's sympathies and ideological positioning by the film exclusively with the soldier, to the exclusion of the perspective of civilians affected by the conflict, the families of the soldiers, and the many other people involved in any war. Pat Aufterheide (1990, p. 84) refers to these films as "noble grunt" stories that portray the soldier's experience on the ground as the only "real" story of the war, inevitably positioning the soldier as both primary agent and victim of the war. This perpetuates the myth that warfare is an activity that concerns mainly military personnel, obscuring the fact that throughout the twentieth century the ratio of civilians to soldiers killed, injured or displaced by war has grown astronomically (Kaldor, 2007, p. 107)

A less common, but potentially more effective tactic to make an antiwar statement is through the depiction of soldiers from both sides of a conflict. Since demonization of the enemy is by far the most important method for justifying a war and for aligning soldier and civilian support behind it, revealing the complexity and humanity of enemy combatants is a powerful and relatively little used tactic to undermine the rationale for any given war. Clint Eastwood's diptych-Flags of Our Fathers and Letters from Iwo Jima-represents a recent attempt to present both sides of a battle with even-handedness (though, unfortunately, Eastwood abandons this approach in American Sniper). Other examples include D.W. Griffith's Birth of a Nation (1914), which follows the Union and Confederate branches of a single family, but which displaces all the dehumanizing animus and blame for the war on African Americans. The most well-known example from twentieth-century cinema is Lewis Milestone's All Quiet on the Western Front (1930), where the main protagonist shares a trench with the Frenchman he has fatally wounded until the latter dies, by which time the hero has gone nearly mad with remorse. In fact, the First World War, considered by most historians as tragically unnecessary, lends itself well to this treatment and, in addition to Milestone's film, we can count The Big Parade (1925), La Grande Illusion (1937), and Paths of Glory (1957).

World War II had to wait much longer for an even-handed treatment of Germans and Japanese, and to this day there are relatively few such attempts. One example is Slaughterhouse Five, which depicts the German soldiers at the end of the war as scruffy and pathetic as the American protagonist, and it also shows the massive civilian population decimated by firebombing in Dresden, thereby complicating facile binary oppositions of righteous Allies and murderous Nazis. For Vietnam, notable examples are Good Morning Vietnam (1987), which allows a Viet Cong fighter an impassioned speech explaining his nationalist motives, Between Heaven and Earth (1993), based on Le Ly Hayslip's autobiographical account of being a Viet Cong cadre, and We Were Soldiers (2002), which offers a humanizing portrayal of the North Vietnamese Army at the Battle of Ia Drang.

Films that attempt to humanize Muslim insurgents are much rarer, though Syriana (2005) shows how vulnerable young Arabs can be seduced into serving as suicide bombers, and Paradise Now (2005) goes even further in providing a complicated and controversial, and some might say sympathetic, portrait of two Palestinian bombers. A few more films have attempted to sympathetically depict Arab civilians, though rarely go so far as to make them full-fledged characters in the narrative. One film that gives an Iraqi civilian an

$\operatorname{imp}$

nam

(actl

in th

$\mathrm{Tl}$

trau

takes

Afte

Ame

on th

the $f$

finis

with

go to

fanta

sequ

by hi

to $\mathrm{M}$

will c

to go

hallu

his $\mathrm{d}$

dinn

preva

a wa

soldi

for th

Th

becor

the tr

Abel

nonre

best $r$

from

wort

ontol

but fi

conju

betwe

poet,

lunat

Alt

its an

a den

of her 
important supporting role is G.I. Jesús (2006), which features a sympathetic character named Mohammed who turns out to be a ghost or figment of a returning soldier's imagination (actually someone he has killed during a raid) and who is given several important speeches in the film denouncing the war.

The example of G.I. Jesús is interesting for another common tactic as well, that of posttraumatic stress disorder (PTSD) or psychological damage resulting from war. The film takes a risk in its use of nonrealism and disruption of linearity in the telling of this story too. After about an hour of film focusing on the increasing difficulties of Jesús, a young MexicanAmerican soldier on leave from duty in Iraq, a narrative arc that ends with the protagonist on the verge of committing a murder in a jealous rage, the story starts over and we realize the first part was a dream. In an uncanny repetition, we watch the protagonist once more finish his flight home and land at LAX to meet his family, only this time everything occurs with a slight difference. When he receives his letter to redeploy he decides immediately to go to Mexico instead, and this time his wife supports him (unlike in the paranoid dream fantasy of the first part). Although the most extreme PTSD symptoms appear in the dream sequence, where he repeatedly talks to the ghost Mohammed while appearing to be talking by himself, and is clearly and literally haunted by perpetrator guilt, he also sees and speaks to Mohammed at the end of the "real" narrative when he is in Mexico, suggesting that he will continue to suffer from psychological symptoms even if he has made the right decision to go AWOL and not redeploy. We learn halfway through the film that the origin of these hallucinations is an incident in which Jesús killed a man (now the ghost Mohammed) and his daughter, a girl very similar to his own in age and appearance, while they were eating dinner in their home. The film uses Mohammed to make a clear statement about the prevalence of the killing of civilians in the war in Iraq, and uses Jesus' guilt-related PTSD as a way of denouncing the war and indirectly warning other green-card soldiers (Latino soldiers who use the military as a means to acquire legal residency and eventual citizenship for themselves and their families) that the price may not be worth it.

The antiwar tactic of stressing psychological damage, shellshock, or PTSD, which has become particularly common since the Vietnam War, has a long and important history in the twentieth century. One of the first and most elaborate examples of this convention was Abel Gance's J'Accuse (1919). Like G.I. Jesús, the film is daring and innovative in its use of nonrealistic devices such as surrealism, the supernatural, and visual allegory. The film is best remembered for the striking sequence near the end where an army of dead soldiers rise from the ground and visit the living as a ghostly cavalcade to see if they (the living) are worthy of their heavy sacrifice. The scene is presented as ambiguous in relation to its ontological status in the film, narrated as a dream recounted by the now-mad protagonist but filmed as if the story he tells were actually happening and the dead really arrive as if conjured by his narrative. The larger arc of this complex narrative involves a love triangle between a woman, Edith, married to a jealous and brutal man while in love with a pacifist poet, Jean Diaz, and the story mainly follows Jean's evolution from gentle poet to raving lunatic as a result of shellshock. ${ }^{5}$

Although the film is an explicit and bitter diatribe against the violence of World War I, its antiwar message is somewhat undercut by two other elements in the film. The first is a demonization of the German soldiers, especially in the repeated scene of Edith telling of her rape at the hands of several soldiers, represented by giant black shadows on the wall. 
In this respect, the film remains thoroughly French in its memory of the war and echoes the iconography of World War I propaganda (which depicted Germans as gorilla-like "Huns"). A second subplot that complicates the antiwar message of the film is the gradual humanization of Jean's rival, François, a man who seems very unlikeable at first and who becomes Jean's closest friend as a result of the bond they share as soldiers despite their rivalry for Edith. The theme of the great love and camaraderie between fighting men is a staple of the pro-war film because it tends to re-enchant war rather than disenchant it. In Gance's film, the experience of hardship and combat clearly has a softening and humanizing effect on François, who becomes a loyal caretaker to the increasingly frail and finally mad Jean. In fact, I would argue that the PTSD tactic has only limited effectiveness as a cinematic argument against war because it is too easily recuperated by the logic that while this particular soldier is driven mad, others are not, and that enduring trauma is an exception that befalls an unlucky or unworthy few. It also lends itself well to the position that while some wars are confusing and psychologically damaging-such as World War I or the Vietnam War-engaging in combat is not necessarily and always a destructive experience, which an antiwar film would want to suggest.

It bears pointing out that PTSD is almost universally invoked by serious films about the Iraq and Afghanistan Wars, most of which take some sort of critical stance about it and its motives, including Home of the Brave (2006), Battle for Haditha (2007), In the Valley of Elah (2007), Redacted (2007), Stop-Loss (2008), and Brothers (2009). ${ }^{6}$ Even the commercially successful The Hurt Locker (2008) makes PTSD its central theme by making its protagonist a man who is something of a functioning PTSD victim (the way we speak of a highfunctioning alcoholic), and has turned his emotional numbness and disconnectedness into a professional asset in his job as a bomb disposal expert. Martin Barker has attributed the commercial success of the film at least in part to its exceptionally apolitical character, to the fact that it is pointedly not an antiwar film in any obvious sense (Barker, 2011, pp. 156-163). Instead, the film's attention is narrowly focused on the psychological state of three main characters over a period of about six weeks. Each of the three reacts in a significantly different way to the stresses of their dangerous job. The main character has successfully compartmentalized all unnecessary or inconvenient feelings and is functioning well if somewhat recklessly (since he seems to have lost any normal sense of self-preservation). Another character is suffering from emotional disturbances and is seeing an army psychologist. The third seems tough and efficient, a no-nonsense, by-the-book officer who resents the hero's maverick ways, but turns out to have the most dramatic character arc of all three, experiencing a conversion resulting in a desire to leave Iraq and start a family. ${ }^{7}$ In stark contrast to the two others, the main character, after spending several surreal and emotionally flat weeks at home with his wife and son, decides to redeploy in order to continue doing what he "loves." The last scene, drawing on conventions of the western and the lone gunslinger hero, shows him back at work. Even if the film suggests that war situations are trauma-inducing, it also leaves the viewer with a sense that living with PTSD is possible and even heroic on some level.

Most recent films evoking PTSD, however, tend to use it as an indirect antiwar argument. For example, a recent Argentinian film tells the story of two men who fought in the Falklands War in 1982 and who suffer from the consequences 20 years later. Illuminados por el fuego (Blessed by Fire, 2005) begins with the suicide of one of the two friends, and gradually 
reveals, through flashbacks and conversations with his wife, how the after-effects of war can slowly but relentlessly corrode a life over decades. Like the other films mentioned, Illuminados por el fuego suggests that soldiers react differently to the same traumas, but that even those who seem to forget and move on carry the burden of what they experienced. In this case, one of the three original friends dies on the island, haunting the other two with his seemingly senseless death over the small British colony made into the object of jingoistic pride by the Argentinian military dictatorship. Although the film comes across as ambivalent about the right of the Falklanders to govern themselves, and clearly against the right of Britain to keep the island for itself, it does seem to suggest that the lives sacrificed in this confrontation were in vain. When the protagonist returns to the island 20 years after the Argentine defeat, everything appears peaceful and well-run, while the battlefield where the protagonists suffered from cold and terror and relentless shelling remains a fenced-off wasteland (mirroring their unhealed memories of the war). The deaths of young men 20 years earlier cannot help but appear misguided and futile rather than glorious.

The war scenes in this film also recall those of the antiwar classic All Quiet on the Western Front (1930) in a number of ways, but most notably in the use of diegetic sound. Sound was fairly recent when All Quiet was made, and the film has been praised for its effective use of sound recording in general, but its most effective use of this new technology is in its attempt to recreate the deafening and relentless sound of shells falling outside the dugout (Kelly, 2006, p. 27). The soundtrack during these scenes is very loud, and the film emphasizes the way in which the bombardment could continue for hours on end, exhausting and maddening the people trapped below. Illuminados por el fuego features similar scenes of the young Argentines hiding in their underground bunkers, unable to sleep, unable to even rest, hounded by the pounding of shells fired from British warships off the coast. The young men are traumatized, helpless, trapped in their dirt hole, nerves wrung to an extreme, exhausted and tortured by the sound and impact of the shells, which sometimes fall so close that the men are covered with earth falling from the walls. There is nothing heroic, glorious, or even courageous about withstanding a deafening artillery bombardment for hours. It is a miserable, supremely passive experience, where survival is a matter of chance. Film captures something of this experience in a way that it cannot approximate with the visual representation of combat. Sound travels by vibration, so a loud soundtrack noise of a bomb can vaguely approximate the discomforting feel of the sound as well as the passivity of simply sitting and waiting for the next bomb or artillery shell to fall, in a way that the spectacle of battle can never approximate the experience or the feeling of being in battle except in its positive aspects (tension, excitement, absorption).

I end with sound because one of the arguments of this chapter has been that the spectacle of war cannot effectively disenchant war and cannot therefore be truly antiwar. As Francis Ford Coppola said in a 2005 interview, to "make a film that is truly antiwar, it would not be set anywhere near battlefields or theaters of war, but rather in human situations far from those" (quoted in Wechsler, 2005, p. 71). Of course, film is not only spectacle: it is also narrative-but, as we have seen, this too tends to shape the violence of war into larger meanings and coherent resolutions. Ultimately, while films can normalize, glamorize, or invest war with magic and meaning, they can only be as antiwar as their viewers already are. Narrative cinema, especially commercial cinema, has too many other objectives to be an effective means of disenchanting warfare, and the conventions of cinematic storytelling do 
not lend themselves well to demystification and political critique. Art can raise questions, but narrative film cannot escape from its inherent tendency to provide semblances of answers in the form of narrative structure and emotional experience. This is why many former soldiers who write novels about and against war are deeply suspicious of film. ${ }^{8}$ In The Thin Red Line (1962), James Jones has the character named Bell think bitterly to himself after a costly attack:

If this were a movie ... When the attack came in the film it would be satisfying. It would decide something. It would have a semblance of meaning and a semblance of an emotion. And immediately after, it would be over. The audience could go home and think about the semblance of meaning and feel the semblance of emotion. Even if the hero got killed, it would still make sense. Art, Bell decided, creative art-was shit. (Jones, 1962, p. 237)

While not sharing Bell's extreme and bitter conclusion, I would suggest that his point about the inevitably sense-making effect of narrative is important and can help explain why the increased realism, cynicism, and critical dimension of recent war cinema has done little to disenchant and discredit war in our time.

\section{Notes}

1 One notable exception to this rule is John Milius, screenwriter for Apocalypse Now (1979) and Red Dawn (1984), who proudly calls himself a "military pornographer"; however, since Milius works mainly in the action-adventure genre this pro-military slant is not surprising (Weschler, 2005, p. 73).

2 Exceptions to this rule include a number of films from the former Axis powers, such as the German Die Brücke (The Bridge, 1959) and the Japanese Nobi (Fires on the Plain, 1959). One American film that struggles bravely to depict the war even-handedly and to suggest that it was a colossal moral catastrophe for everyone involved is George Roy Hill's Slaughterhouse Five (1972). Like Kurt Vonnegut's book, the film undermines the triumphalism of Allied victory and questions the idea that any redeeming value can be wrested from the slaughter committed by both sides by reminding viewers of Allied atrocities such as the firebombing of German cities. Nevertheless, that was in 1972 and the film was clearly influenced by the failing war in Vietnam. Clint Eastwood's recent revisiting of World War II adopts a very different tone. In his respectful Iwo Jima diptych, Flags of Our Fathers (2006) and Letters from Iwo Jima (2006), everyone is a hero, the Japanese as well as the Americans-and the sense of bitter condemnation in Hill's film is replaced by reverence and gratitude.

3 As I write this, the David Ayer film Fury (2014) is reaching new heights (or lows, rather) of screen carnage, with exploding heads, bayonets in the eye, pieces of a man's face, bodies squashed by tanks, limbless bodies, and a feast of blood and gore from beginning to end.

4 Conversely, films that support war tend to show older and more mature soldiers. Again, Wayne's pro-war The Green Berets is a good example, with no soldier under thirty in the entire movie and Wayne himself looking too old for the part he's playing.

5 The film represents his madness in a typical World War I sense, not because of having seen or done disturbing things, but literally the result of a shell exploding too close to him. For a useful definition and discussion of PTSD, see Lockhurst (2008).

6 In fact, since the 1970s, when the term was first invented and accepted into the Diagnostic and Statistical Manual of Mental Disorders, PTSD has been a common theme in war films in general, e.g. Taxi Driver (1976), First Blood (1982), Brodre (2004), Waltz with Bashir (2008). Post-combat 
trauma has appeared in films throughout the century (known as shell shock, soldier's heart, battle fatigue, etc.) but became a cliché only after Vietnam.

7 On Sanborn's conversion, see Cunningham (2010).

8 Dalton Trumbo offers an interesting example of an antiwar writer (though not a veteran) who also directs the film adaptation of his novel, Johnny Got His Gun. One can notice that he not only avoids combat scenes but uses several antiwar devices listed above, including the soldier's extreme youth, attachment to sweetheart, nonlinear structure, lack of closure, fallibility of officers, the role of chance in injury, and an emphasis on dismemberment (the protagonist has no limbs or face), to drive home the film's antiwar message.

\section{References}

All Quiet on the Western Front (1930) USA, dir. Lewis Milestone, Universal Pictures. American Sniper (2014) USA, dir. Clint Eastwood, Village Roadshow Productions.

Aufterheide, Pat (1990) Vietnam: Good soldiers, in Seeing Through the Movies (ed. Mark C. Miller), Pantheon, New York, pp. 81-111.

Barker, Martin (2011) A "Toxic Genre": The Iraq War Films, Pluto Press, London.

Between Heaven and Earth (1933) USA, dir. Oliver Stone, Le Studio Canal + \& Regency Enterprises. Bierce, Ambrose (1966) The Collected Works of Ambrose Bierce, vol. II. Gordian Press, New York.

Birth of a Nation (1915) USA, dir. D.W. Griffith, David W. Griffith Corp.

Brodre (2004) Denmark, dir. Susanne Bier, Zentropa.

Broyles, William, Jr. (1984) Why Men Love War. Esquire (November). http://public.wsu.edu/ hughesc/ why_men_love_war.htm (accessed 19 November 2015).

Cole, Sarah (2009) Enchantment, disenchantment, war, literature. PMLA, 124 (25), 1632-1647.

Come and See (1985) USSR, dir. Elem Klimov, Mosfilm \& Belarusfilm.

Cunningham, Douglas (2010) Explosive structure: Fragmenting the new modernist war narrative. CineAction, 81. http://cineaction.ca/issue81 sample.htm (accessed 18 November 2015).

Die Brücke (The Bridge) (1959) West Germany, dir, Bernhard Wicki, Deutsche Film Hansa.

Doherty, Thomas (2013) Projections of War: Hollywood, American Culture, and World War II, Columbia University Press, New York.

Dawson, Graham (1994) Soldier Heroes: British Adventure, Empire and the Imagining of Masculinities, Routledge, London and New York.

Ebert, Roger (1986) Review of "Platoon." Chicago Sun Times (30 December). http://rogerebert. suntimes.com/apps/pbcs.dll/article?AID=/19861230/REVIEWS/612300301/1.023 (accessed 22 November 2015).

First Blood (1982) USA, dir. Ted Kotcheff, Anabasis Investments.

First Kill (2001) Holland, dir. Coco Schrijber, Lemming Film.

Full Metal Jacket (1987) UK \& USA, dir. Stanley Kubrick, Natant \& Harrier Films.

Fury (2014) USA, dir. David Ayer, Le Grisbi Productions.

Gallipoli (1981) Australia, dir. Peter Weir, Associated R \& R Films.

G.I. Jesus (2006) USA, dir. Carl Colpaert, Cinefrontera.

Good Morning Vietnam (1987) USA, dir. Barry Levinson, Touchstone Pictures.

Grave of the Fireflies (1988) Japan, dir. Isao Takahata, Studio Ghibli.

Hanich, Julian (2008) A weep in the dark: Tears and the cinematic experience, in Passionate Politics: The Cultural Work of American Melodrama from the Early Republic to the Present (eds. Ralph J.

Poole and Ilka Saal), Cambridge Scholars Publishing, Newcastle, pp. 27-45.

Hearts and Minds (1974) USA, dir. Peter David, BBS Productions.

Hedges, Chris (2002) War Is a Force That Gives Us Meaning, Anchor Books, New York. 
Herr, Michael (1978) Dispatches, Avon, New York.

Horne, Thomas (2010) Goliath in the Valley of Elah. War, Literature and the Arts 23 (1), 252. http://

www.wlajournal.com/22_1-2/images/horne.pdf (accessed 19 November 2015).

Illuminados por el fuego (2005) Argentina, dir. Tristán Bauer, Canal + España.

In the Valley of Elah (2007) USA, dir. Paul Haggis, Summit Entertainment.

Iser, Wolfgang (1978) The Act of Reading, Johns Hopkins University Press, Baltimore, MD.

J’Accuse (1919) France, dir. Abel Gance. Pathé Frères.

Johnny Got His Gun (1971) USA, dir. Dalton Trumbo, World Entertainment.

Jones, James (1962) The Thin Red Line, Delta, New York.

Kaldor, Mary (2007) New and Old Wars, $2^{\text {nd }}$ edn., Stanford University Press, Stanford, CA.

Kelly, Andrew (2006) On the greatness and continuing significance of All Quiet on the Western Front,

in The War Film (ed. Robert Eberwein), Rutgers University Press, New Brunswick, NJ, pp. 23-29.

Koppes, Clayton R., and Black, Gregory D. (1987) Hollywood Goes to War, University of California

Press, Berkeley and Los Angeles.

Kovic, Ron (1976) Born on the Fourth of July, Pocket Books, New York,

Kyle, Chris with McEwen, Scott and DeFelice, Jim (2012) American Sniper: The Autobiography of the

Most Lethal Sniper in U.S. Military History, Harper, New York.

La Grande Illusion (1937) France, dir. Jean Renoir, Réalisations d'Art Cinématographique (RAC).

Levander, Caroline F. and Singley, Carol J. (2003) Introduction, in The American Child: A Cultural

Studies Reader (eds. Caroline F. Levander and Carol J. Singley), Rutgers University Press, New Brunswick, NJ, pp 3-12.

Lichty, Lawrence W. and Carroll, Raymond L. (2008) Fragments of war: Oliver Stone's Platoon, in Why

We Fought: America's Wars in Film and History (eds. Peter C. Rollins and John E. O'Connor)

University Press of Kentucky, Lexington, KY, pp. 390-403.

Lockhurst, Roger (2008) The Trauma Question, Routledge, New York.

May, Lary (2006) Hollywood and the World War II conversion narrative. Hollywood and War: The

Film Reader (ed. David Slocum), Routledge, New York, pp. 183-194.

Mayne, Judith (1993) Cinema and Spectatorship, Routledge, New York.

Nobi (Fires on the Plain) (1959) dir. Kon Ichikawa, Daiei Studios.

Owen, Wilfred (1963) The Collected Poems of Wilfred Owen, ed. C. Day Lewis, Chatto \& Windus, London.

Overlord (1975) UK, dir. Stuart Cooper, Joswend.

Paths of Glory (1957) USA, dir. Stanley Kubrick, Bryna Productions.

Saving Private Ryan (1998) USA, dir. Steven Spielberg, Amblin Entertainment.

Schatz, Thomas (2006) World War II and the Hollywood "War Film," in Hollywood and War: The Film Reader (ed. David Slocum), Routledge, New York, pp. 147-156.

Sgt. York (1941) USA, dir. Howard Hawks, Warner Bros.

Silverman, Kaja (1986) Suture [Excerpts], in Narrative, Apparatus, Ideology: A Film Theory Reader (ed. Philip Rosen), Columbia University Press, New York, pp. 219-235.

Slaughterhouse Five (1972) USA, dir. George Roy Hill, Universal Pictures.

Smith, Larry (2006) The Few and the Proud, Norton \& Co., New York.

Sokolowsky-Paryz, Marzena (2012) The narration and visualization of rape and the inadvertent subversion of the antiwar message in Brian de Palma's Redacted and Casualties of War. War, Literature and the Arts, 24 (2012). http://wlajournal.com/24_1/pdf/Sokolowska-Paryz.pdf (accessed 19 November 2015).

Soltysik, Agnieszka M. (2008) Melodrama and the American combat film, in Passionate Politics: The Cultural Work of American Melodrama from the Early Republic to the Present (eds. Ralph J. Poole and Ilka Saal), Cambridge Scholars Publishing, Newcastle, pp. 165-186.

Springer, Claudia (1988) Antiwar film as spectacle: Contradictions of the combat sequence. Genre, XXI, 479-486. 
Staiger, Janet (1992) Interpreting Films, Princeton University Press, Princeton, NJ.

Stowe, Harriet Beecher (1994) Uncle Tom's Cabin, Norton Critical Edition, Norton \& Co., New York. Sturken, Marita (1997) Tangled Memories: The Vietnam War, the AIDS Crisis and the Politics of Remembering, University of California Press, Berkeley, CA.

Suid, Lawrence H. (2002) Guts and Glory: The Making of the American Military Image in Film, University of Kentucky Press, Lexington, KY.

Swofford, Anthony (2003) Jarhead: A Marine's Chronicle of the Gulf War, Scribner, London.

Syriana (2005) USA, dir. Stephen Gaghan, Particpant Media.

Taxi Driver (1976) USA, dir. Martin Scorcese. Bill/Phillips.

The Best Years of Our Lives (1946) USA, dir. William Wyler, Samuel Goldwyn. Productions.

The Big Parade (1925) USA, dir. King Vidor, MG M.

The Children of Huang Shi (2008) Australia, China, Germany, dir. Roger Spottiswoode, Australian

Film Finance Corporation.

The Green Berets (1968) USA, dir. Roy Kellogg \& John Wayne, Batjac Productions.

The Hurt Locker (2009) USA, dir. Kathryn Bigelow, Voltage Pictures.

The Thin Red Line (1998) USA, dir. Terence Malick, Geisler Roberdeau.

Turtles Can Fly (2004) Iran, France, dir. Bahman Ghobadi, Mij Films.

Vietnam in the Year of the Pig (1968) USA, dir. Emile de Antonio, Emile De Antonio Productions.

Waltz with Bashir (2008) Israel, dir. Ari Folman, Bridgit Folman Film Gang.

Wechsler, Lawrence (2005) Valkyries over Iraq. Harper's Magazine, (November) pp. 65-77.

Whitman, Walt (1996) Walt Whitman: Poetry and Prose, Library of America, New York.

Williams, Linda (1998) Melodrama revised, in Refiguring American Film Genres (ed. Nick Browne),

University of California Press, Berkeley, pp. 42-88.

Winter Soldier (1971) USA, dir. Vietnam Veterans against the War, The Winterfilm Collective.

\section{Further Reading}

Kinney, Katherine (2000) Friendly Fire: American Images of the Vietnam War, Oxford University Press, Oxford and New York.

Polner, Murray and Woods, Thomas E., Jr. (2008) We Who Dared Say No to War: American Antiwar Writing from 1812 to Now - Liberals Who Have Opposed America's Wars, Basic Books, New York. 